Received 04.05.2016 Reviewed 13.07.2016 Accepted 02.08.2016

A - study design

B - data collection

C - statistical analysis

D - data interpretation

$\mathbf{E}$ - manuscript preparation

$\mathbf{F}$ - literature search

\title{
Potential possibilities of water retention in agricultural loess catchments
}

\author{
Tomasz ZUBALA ${ }^{\text {ABCDEF }}$, Magdalena PATRO ${ }^{\text {BCDEF }}$
}

University of Life Sciences in Lublin, Department of Environmental Engineering and Geodesy, ul. kr. St. Leszczyńskiego 7 , 20-069 Lublin, Poland; e-mail: tomasz.zubala@interia.pl,magdalenapatro@wp.pl

For citation: Zubala T., Patro M. 2016. Potential possibilities of water retention in agricultural loess catchments. Journal of Water and Land Development. No. 30 p. 141-149. DOI: 10.1515/jwld-2016-0030.

\begin{abstract}
The growing water deficit and the increased demand for water, as well as economic problems and inadequate spatial planning in many regions indicate a necessity of developing more effective rules of programming and realisation of works concerning the water management in small catchments. The paper presents a sample analysis of the possibilities of increasing water retention in the agricultural loess catchments with periodic streams. The scope of the study included the determination of physical parameters of selected sub-catchments (geometry, soil cover, land use, etc.) and of the sources of threat to water resources, resulting from construction and geomorphological conditions. Pre-design assumptions of dammings were developed, taking into account anti-erosion protective measures, and treatments increasing the landscape retention of water were proposed. Creating surface retention objects should be an important source of water in simplified agroecosystems, especially in regions, where productivity to a great extent depends on natural weather conditions. Proper management of the fourth-order loess basin of the Ciemiega River (area of about $150 \mathrm{~km}^{2}$, the presence of 50 lateral valleys) could give a temporary reservoir retention reaching 500 thousand $\mathrm{m}^{3}$. Farmers should be encouraged to seek "own water sources" (including the accumulation of water within wasteland), using appropriate economic instruments (tax reliefs for the documented volume of retained water, e.g. in small retention reservoirs).
\end{abstract}

Key words: agricultural catchment, reservoirs, retention, water resources

\section{INTRODUCTION}

Water is of an enormous importance in the shaping of the natural environment, and constitutes also a significant determinant for sustainable social and economic development [DAVIS 2007; GORDON et al. 2010; MIRCHI et al. 2014]. Many regions of the world, including Central and Eastern Europe have modest water resources, and their availability is very often limited due to poor quality. For example, the renewable resources of surface waters per inhabitant in Poland amount to $1655 \mathrm{~m}^{3}$, with a dry-year minimum of $1100 \mathrm{~m}^{3}$ (mean annual runoff from a given area) [Eurostat 2011]. Whereas, according to a FAO report [FAO 2003], countries with less than $1000 \mathrm{~m}^{3}$ of wa- ter per inhabitant per year are considered as suffering from a deep deficit which may be a fundamental cause of inhibition of economic development, and agriculture in particular [BOUWER 2000; GRAYMAN et al. 2012].

In agricultural areas the effects of water deficit are manifested in a considerable reduction of productivity, lowering of ground water table, reduced flow in water courses, disappearance of water in small reservoirs and limiting biodiversity. Due to those threats there is a need to accumulate water in periods of its abundance for use in periods of its deficit [EEA 2012; KOWALEWSKI 2003; MIODUSZEWSKI 1994].

There are many methods of increasing the retention capacity of agricultural catchments. Those used 
in the case of surface water retention include, among other things, regulation of outflow from ponds, accumulation of water in melioration ditches, increase of valley retention, but primarily the construction of reservoirs on water courses. Creating reservoirs also influences the regulation of flow, increases ground water resources and limits erosion [DEITCH et al. 2013; MiODUSZEWSKI 1994; 2012].

The extension of water retention in sub-catchments is, in many cases, the condition for the creation of reservoir retention in larger river valleys (e.g. upland erosive areas). The migration of biogenic components and suspended matter, and the high capacity of reservoirs to retain certain contaminants determine the serious threat of eutrophication processes. In numerous cases the accumulation of biogenic elements and bottom sediments significantly reduces the economic value of reservoirs and renders their exploitation impossible [JUSZCZAK, KĘDZIORA 2003; PATRO, ZUBALA 2012; WHITE et al. 1996; ZuBALA 2009].

In the deficit regions, programs of retention increasing should include complex operations in the range of water management in small river basins for the purpose of improvement of water resources and their rational use, taking into account both the economic needs and the requirements of the natural environment [MIODUSZEWSKI 2003]. The theoretical assumptions often look very good, but it is usually a long way to the success. In developing countries, the reasons are low financial investments and complicated formal procedures. The small increase of the amount of stored water is also a result of poor utilisation of the retention capacity of melioration systems which constitute an important element of infrastructure of agricultural areas [KOWALEWSKI 2008].

The objective of this paper is to present a concept of increasing water retention in loess micro-catchments, based primarily on the construction of small reservoirs in the bottoms of slope catchments with periodic flow and on correcting selected landscape elements. Special attention was devoted to the pre-design studies covering agricultural upland areas outside of the basic water courses of the drainage basin. In such countries as Poland, for decades improperly implemented spatial planning (including the construction of settlements on the valleys of large rivers), which makes small agricultural catchments of particular importance in the development of water resources. Creating surface retention objects would be an important source of water in simplified agroecosystems. This would contribute to independence of productivity from natural weather conditions.

\section{MATERIALS AND METHODS}

The research objects are situated within the mesoregion Nałęczowski Plateau in the drainage basin of the Ciemiega River (neighborhood of Lublin agglomeration). Most of the area of the drainage basin is included in the Ciemiegga Valley Protected Land- scape Area. That sub-region is extremely poor in surface waters.

The research works were carried out successively (by stages) in the years 2000-2013. The development of the pre-design assumptions was preceded with numerous field observations, surveys at the locations of the reservoirs, and analyses of cartographic materials (topographic maps 1:10 000, cadastral maps 1:5 000). The detailed scope of the work included the determination of boundaries and physical parameters of catchments of the reservoirs; determination of dimensions and methods of construction of the reservoirs; calculation of the volume of earth masses moved (method of surface levelling along profiles with determination of basic geometric solids). The analysis and presentation of the basic parameters of the studied catchments (e.g. land relief) was possible thanks to the performing of a numerical model of the area by means of the program ArcGIS (Spatial Analyst). The image obtained was superimposed on a topographic map at 1:10 000 (geodesy geographic coordinates in the EUREF-89 system). The analyses included also meteorological, hydrological and hydrogeological observations conducted in the research area in the years 2000-2003. Measurements of daily precipitation totals in the area of research catchments were performed with Hellmann rain gauge (the own rainfall station). In order to recognise the size of barren surface runoff, hydrometric measurement sites were established on watercourses. In these places water levels were measured, and the flow rate at different filling of river-beds were determined. The measurement results were the basis for plotting discharge curves for particular hydrometric profiles. The readings of water levels were performed systematically once a day, except for periods of snow melting, when the registration was carried out several times a day. Measurements of flow rates were performed once every 10 days with the method of collecting vessel - using baffles (flow of less than $3 \mathrm{dm}^{3} \cdot \mathrm{s}^{-1}$ ) or with a hydrometric mill HEGA-1 (flow of more than $3 \mathrm{dm}^{3} \cdot \mathrm{s}^{-1}$ ). Due to technical and financial limitations and the location of the catchment 3 in the catchment 2, the research of surface runoffs was conducted only in the estuary sections of the catchment 1 and 2 .

In the area of all planned reservoirs, observations of changes of groundwater table levels were performed. The measuring sites were located in the valley bottoms and slopes on both sides of watercourses. Depending on a width of a valley bottom and landform feathures of the adjacent area, 3 to 4 piezometers were installed on each side (extreme positions were 30-70 meters away from a streamline). Wells were done to the depth from $150 \mathrm{~cm}$ (a valley bottom) to $300 \mathrm{~cm}$ (slopes). Groundwater levels were recorded at intervals of ten days.

In the vicinity of the planned reservoirs, research on soil and ground was also performed. The exact profile of the area, thickness of humus and transitional horizons, and the depth of parent rock were deter- 
mined. Location of the particular layers was established on the basis of range drilling. Soil pits were done on each route. Material for analyses of physical properties was taken from characteristic levels and layers (e.g. the granulometric composition - Bouyoucos-Casagrande's areometric method, the density of the solid phase - pycnometer method, the permeability of water - permeameter of Eijkelkamp company). On each side of the watercourse 3 soil pits were located (the valley floor, the slope, the beginning of the plateau).

\section{RESULTS AND DISCUSSION}

\section{GEOMETRY, SURFACE FEATURES AND CATCHMENT USE}

Three neighbouring catchments were selected for the study, catchment No. 3 being situated within the area of catchment No. 2 - constituting its upper part (a system of two reservoirs was planned in the bottom of the same valley), while only one water reservoir is considered for construction in catchment No. 1 (Fig. 1).

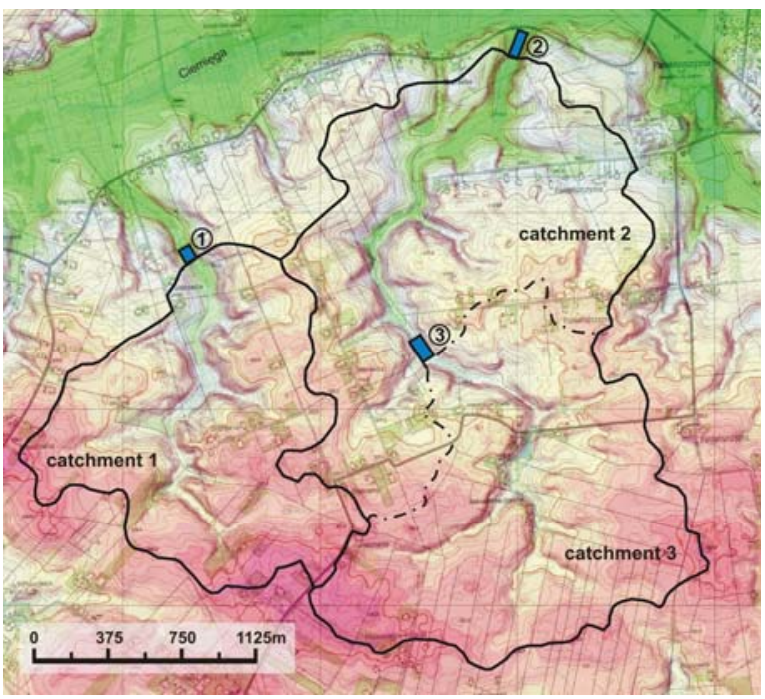

Fig. 1. Location of studied catchments; source: own elaboration

The catchments occupy a combined area of 630 ha and they are situated between ordinates 195 and $234 \mathrm{~m}$ a.s.l. The mean altitudes are from 214.5 (catchment 2) to $220.5 \mathrm{~m}$ a.s.l. (catchment 3), at average slopes from 1.84 (catchment 2) to $2.52 \%$ (catchment 1). The maximum slopes occur in the axial parts of the catchments (valley slopes sloping towards the lines of the water courses) and in their upper parts (bifurcations of main valleys). Regions with the least slopes predominate on the hilltops and in depressions of the ground. In the area under study steep and short slopes dominate (Phot. 1).

The differences in elevation between the watershed and the valley bottoms reach $20 \mathrm{~m}$. The width of the bottoms of the main valleys varies within the range of $20-120 \mathrm{~m}$. The lengths of the catchments

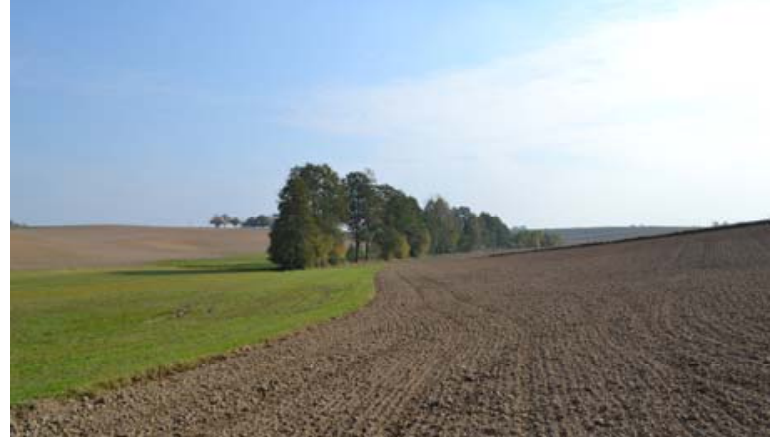

Phot. 1. Adjacent surroundings of planned reservoir No. 1; (photo T. Zubala)

along the axes of the main valleys vary from 1.67 (catchment 1) to $3.10 \mathrm{~km}$ (catchment 2), while mean widths attain values from about 1 (catchments 1 and 3) to $1.45 \mathrm{~km}$ (catchment 2). The highest value of elongation index is characteristic of catchment 1 (0.91) which is, like catchment 2 , divided asymmetrically by the bed of the water course (Tab. 1).

Table 1. Physical characteristics of catchments

\begin{tabular}{|l|c|c|c|}
\hline \multicolumn{1}{|c|}{$\begin{array}{c}\text { Geometry } \\
\text { and surface features }\end{array}$} & $\begin{array}{c}\text { Catchment } \\
1\end{array}$ & $\begin{array}{c}\text { Catchment } \\
2\end{array}$ & $\begin{array}{c}\text { Catchment } \\
3\end{array}$ \\
\hline Area, km ${ }^{2}$ & 1.82 & 4.48 & 2.07 \\
\hline Length, km & 1.67 & 3.10 & 2.05 \\
\hline Perimeter, km & 6.89 & 10.17 & 6.96 \\
\hline Compactness coefficient & 1.43 & 1.34 & 1.35 \\
\hline Elongation ratio & 0.91 & 0.77 & 0.79 \\
\hline Mean altitude, m a.s.l. & 217 & 214.5 & 220.5 \\
Extreme altitudes, m a.s.l. & $200-234$ & $195-234$ & $207-234$ \\
\hline Slope, \% & 2.52 & 1.84 & 1.88 \\
Maximum slope, \% & 17 & 20 & 17 \\
\hline Land use (ha /\%) & \multicolumn{3}{|c|}{} \\
\hline Arable lands & $156.4 /$ & $370.9 /$ & $185.5 /$ \\
& 85.9 & 82.8 & 89.6 \\
\hline Grasslands & $4.3 / 2.4$ & $24.9 / 5.6$ & $7.7 / 3.7$ \\
\hline Orchards & $13.0 / 7.1$ & $22.7 / 5.1$ & $6.6 / 3.2$ \\
\hline Wastelands & $0.5 / 0.3$ & $12.1 / 2.7$ & $2.6 / 1.3$ \\
\hline Forests, shelterbelts & $0.2 / 0.1$ & $1.0 / 0.2$ & $0.1 / 0.0$ \\
\hline Built-up areas, roads & $7.3 / 4.0$ & $15.3 / 3.4$ & $3.7 / 1.8$ \\
\hline Surface waters & $0.3 / 0.2$ & $1.1 / 0.2$ & $0.8 / 0.4$ \\
\hline
\end{tabular}

Source: own study.

The catchments are drained by means of shallow melioration ditches, not maintained for many years. Their depths at the outlet sections do not exceed 0.6 $\mathrm{m}$. The average slopes of their channels are about $0.6 \%$.

The dominant land use type in the research area is agricultural lands. They occupy $94 \%$ of the total area, arable lands accounting for nearly $84 \%$ of the area, and remaining small amount of about $10 \%$ being grasslands and orchards (Tab. 1). Pastures and meadows dominate in the lower parts of the slopes and in the bottom of the valley (Phot. 1). In the outlet section they are often strongly waterlogged, which makes their use difficult. Forests and shelterbelts constitute only $0.2 \%$ of the total area. Shelterbelts can be encountered primarily in the vicinity of buildings and 
along water courses. Location of reservoirs must take into account the presence of few groups of trees in the valley bottoms. A very small share of trees on such areas and the need to maintain the greatest biodiversity exclude the possibility of removing even individual trees [BROCKERHOFF et al. 2008; HIETALA-KOIVU et al. 2004]. Terrains under water constitute a total of 1.4 ha, which is only $0.2 \%$ of the total area. The remaining part of the area is occupied by built-up areas and roads. The total length of roads within the catchments under analysis is approximately $37 \mathrm{~km}$, a large part of which is unhardened.

Arable fields in the research area have the form of elongated rectangles, their longer borders often running along the lines of the steepest slopes. As a consequence, the non-favourable cultivation along the slope is conducted. With such an arrangement of the fields, the conventional tillage treatments accelerate and amplify the processes of erosion [BOARDMAN, POESEN 2006; VAN OOST et al. 2000]. The arrangement of the plots affects also the situation of the access roads. In many cases they run along the slope lines. Thus the roads become the runoff channels of eroded soil, and in extreme cases they transform into impassable ravines [JÓZEFACIUK, JÓZEFACIUK 1999].
The small surface areas and the compact shapes of the catchments, the specific relief of the area (undulating hilltops transiting into steep slopes, bifurcated valley), the arrangement of the roads and the absence of forests are factors accelerating water runoff from the area studied. The runoff is additionally facilitated by the ditches which perform only the drainage function [SKAGGS et al. 1994].

\section{SOIL AND GROUND CONDITIONS}

Selected properties of the soil in the research transverse profiles made in the region of the planned reservoirs are presented in Table 2. The depth of the humus horizon varies from 0.2 (steep slopes) to $0.7 \mathrm{~m}$ (food of slopes with deposited products of erosion). The humus horizon overlies a transition layer with depth from 0.6 to $1.8 \mathrm{~m}$. That layer merges into the loess bedrock. In the bottom of the valley there is a thick layer of diluvial formations, and groundwater table stagnates often shallowly beneath the ground surface. Anaerobic conditions are conducive to gleying processes and to the formation and accumulation of large amounts of organic mater retaining the features of moorsh.

Table 2. Selected physical properties and grain-size distribution of soil in measuring cross-sections of catchments (shown extreme values and average)

\begin{tabular}{|c|c|c|c|c|c|c|c|c|}
\hline \multirow{3}{*}{ Soil properties } & \multicolumn{4}{|c|}{ Valley bottoms } & \multicolumn{4}{|c|}{ Slopes } \\
\hline & \multicolumn{8}{|c|}{ Depth, cm } \\
\hline & $20-25$ & $55-60$ & $80-85$ & $95-100$ & $15-20$ & $55-60$ & $90-95$ & $105-110$ \\
\hline Bulk density, $\mathrm{Mg} \cdot \mathrm{m}^{-3}$ & $\begin{array}{c}0.90-1.44 \\
(1.18)\end{array}$ & $\begin{array}{c}0.45-1.64 \\
(1.04)\end{array}$ & $\begin{array}{c}1.57-1.65 \\
(1.62)\end{array}$ & $\begin{array}{c}0.39-1.59 \\
(1.06)\end{array}$ & $\begin{array}{c}1.39-1.61 \\
(1.55)\end{array}$ & $\begin{array}{c}1.48-1.59 \\
(1.54)\end{array}$ & $\begin{array}{c}1.51-1.68 \\
(1.61)\end{array}$ & $\begin{array}{c}1.52-1.67 \\
(1.60)\end{array}$ \\
\hline Total porosity, $\%$ & $\begin{array}{c}41.1-62.0 \\
(50.3)\end{array}$ & $\begin{array}{c}31.7-81.7 \\
(56.9)\end{array}$ & $\begin{array}{c}39.9-40.9 \\
(40.3)\end{array}$ & $\begin{array}{c}38.6-79.5 \\
(56.8)\end{array}$ & $\begin{array}{c}38.0-47.4 \\
(41.4)\end{array}$ & $\begin{array}{c}41.0-43.3 \\
(41.9)\end{array}$ & $\begin{array}{c}35.8-42.9 \\
(38.4)\end{array}$ & $\begin{array}{c}33.8-42.9 \\
(38.4)\end{array}$ \\
\hline $\begin{array}{l}\text { Filtration coefficient } \\
\left(\mathrm{cm} \cdot \mathrm{s}^{-1}\right) \cdot 10^{-6}\end{array}$ & $\begin{array}{c}58-1899 \\
(526)\end{array}$ & $\begin{array}{c}12-458 \\
(209)\end{array}$ & - & $\begin{array}{c}161-254 \\
(208)\end{array}$ & $\begin{array}{c}11-242 \\
(112)\end{array}$ & $\begin{array}{c}77-289 \\
(174)\end{array}$ & $\begin{array}{c}19-59 \\
(34)\end{array}$ & $\begin{array}{c}33-398 \\
(216)\end{array}$ \\
\hline Sand, \% & $\begin{array}{c}0.1-0.9 \\
(0.5) \\
\end{array}$ & $\begin{array}{c}1.3-2.0 \\
(1.7)\end{array}$ & $\begin{array}{c}0.1-0.6 \\
(0.4) \\
\end{array}$ & - & $\begin{array}{c}0.1-1.0 \\
(0.5) \\
\end{array}$ & $\begin{array}{c}0.1-0.7 \\
(0.3) \\
\end{array}$ & $\begin{array}{c}0.1-1.5 \\
(0.8) \\
\end{array}$ & $\begin{array}{c}0.3-1.0 \\
(0.7) \\
\end{array}$ \\
\hline Silt, \% & $\begin{array}{c}59.9-67.4 \\
(64.5)\end{array}$ & $\begin{array}{c}46.7-52.0 \\
(49.4)\end{array}$ & $\begin{array}{c}42.4-61.9 \\
(50.3)\end{array}$ & - & $\begin{array}{c}59.8-62.0 \\
(60.9)\end{array}$ & $\begin{array}{c}65.3-71.9 \\
(67.7)\end{array}$ & $\begin{array}{c}52.5-62.3 \\
(57.2)\end{array}$ & $\begin{array}{c}59.7-68.0 \\
(63.9)\end{array}$ \\
\hline Clay, $\%$ & $\begin{array}{c}32-40 \\
(35) \\
\end{array}$ & $\begin{array}{c}46-52 \\
(49) \\
\end{array}$ & $\begin{array}{l}38-57 \\
(49.3) \\
\end{array}$ & - & $\begin{array}{c}37-40 \\
(39) \\
\end{array}$ & $\begin{array}{c}28-34 \\
(32) \\
\end{array}$ & $\begin{array}{c}37-46 \\
(42) \\
\end{array}$ & $\begin{array}{c}31-40 \\
(36)\end{array}$ \\
\hline
\end{tabular}

Source: own study.

In the bottoms of the valleys numerous interbeddings were observed, with thickness from several to over a dozen centimetres and with composition typical for silty clays (content of fraction $<0.02 \mathrm{~mm}$ exceeding 50\%). The layers forming the ground are characterised primarily by a low solid phase density $\left(1.9-2.48 \mathrm{Mg} \cdot \mathrm{m}^{-3}\right.$ ) and bulk density (minimum of $\left.0.39 \mathrm{Mg} \cdot \mathrm{m}^{-3}\right)$. Whereas, they have a high total porosity (maximum of $81.7 \%$ ) and permeability (in the upper horizon the filtration coefficient attains values of ca. $0.002 \mathrm{~cm} \cdot \mathrm{s}^{-1}$ ). In the bottoms of the valleys there are also formations with totally different physical properties. For example, in the control profile of catchment 2 at the depth of $0.8 \mathrm{~m}$ the density of the solid phase increases to $2.7 \mathrm{Mg} \cdot \mathrm{m}^{-3}$, and bulk density is as high as $1.65 \mathrm{Mg} \cdot \mathrm{m}^{-3}$. In that horizon the value of the filtration coefficient drops to zero, and total poros- ity is lower by $20-40 \%$ compared to the layers situated above. The presence of layers with limited permeability reduces water drainage through the ground, which is favourable in the case of reservoir construction in the valley bottom [KAWAMURA 2000].

\section{HYDROLOGICAL CONDITIONS}

Outflows from individual slope catchments could amount to as much as $0.046 \mathrm{hm}^{3} \cdot \mathrm{km}^{-2}$ a year (Tab. 3). The unit flows $(q)$ in the control catchments were comparable and varied within the range of 1.1-1.5 $\mathrm{dm}^{3} \cdot \mathrm{s}^{-1} \cdot \mathrm{km}^{-2}$. The maximum recorded flow rate $\left(Q_{\max }\right)$ in a water course was $192.0 \mathrm{dm}^{3} \cdot \mathrm{s}^{-1}$ (catchment 1). A decidedly greater part of the surface outflow occurred in the winter half-year (80-98\% of annual outflow). 
Table 3. Precipitation sums and surface runoff indicators in the studied catchments in 2001-2003

\begin{tabular}{|c|c|c|c|c|c|c|c|c|c|c|}
\hline \multirow{3}{*}{\multicolumn{2}{|c|}{$\begin{array}{c}\text { Observation } \\
\text { period }\end{array}$}} & \multirow{3}{*}{$\begin{array}{c}\text { Precipitation } \\
\mathrm{mm}\end{array}$} & \multicolumn{4}{|c|}{ Catchment 1} & \multicolumn{4}{|c|}{ Catchment 2} \\
\hline & & & $Q_{\max }$ & $Q_{\text {si }}$ & \multirow{2}{*}{$\mathrm{dm}^{3} \cdot \mathrm{s}^{-1} \cdot \mathrm{km}^{-2}$} & \multirow{2}{*}{$\begin{array}{c}V \\
\mathrm{hm}^{3}\end{array}$} & $Q_{\max }$ & $Q_{\text {sr }}$ & \multirow{2}{*}{$\mathrm{dm}^{3} \cdot \mathrm{s}^{-1} \cdot \mathrm{km}^{-2}$} & \multirow{2}{*}{$\begin{array}{c}V \\
\mathrm{hm}^{3}\end{array}$} \\
\hline & & & & & & & & & & \\
\hline \multirow{3}{*}{$\begin{array}{l}2001 / \\
2002\end{array}$} & XI-IV & 204 & 87.0 & 5.0 & 2.7 & 0.078 & 78.0 & 10.7 & 2.4 & 0.167 \\
\hline & $\mathrm{V}-\mathrm{X}$ & 338 & 4.0 & 0.3 & 0.2 & 0.005 & 24.0 & 2.5 & 0.6 & 0.040 \\
\hline & XI-X & 542 & 87.0 & 2.6 & 1.4 & 0.083 & 78.0 & 6.6 & 1.5 & 0.207 \\
\hline \multirow{3}{*}{$\begin{array}{l}2002 / \\
2003\end{array}$} & XI-IV & 130 & 192.0 & 3.9 & 2.1 & 0.061 & 158.0 & 8.2 & 1.8 & 0.128 \\
\hline & $\mathrm{V}-\mathrm{X}$ & 292 & 1.8 & 0.06 & 0.03 & 0.001 & 6.0 & 1.6 & 0.4 & 0.026 \\
\hline & XI-X & 422 & 192.0 & 2.0 & 1.1 & 0.062 & 158.0 & 4.9 & 1.1 & 0.154 \\
\hline
\end{tabular}

Source: own study.

The obtained results confirmed that the rhythm of outflow from the catchments was determined primarily by the character of supply. The source of supply was rainfall which, especially in the cold season, participated immediately, via surface runoff, in the outflow, and snowfall - supplying the outflow in periods of thaw. Apart from violent and short-lasting high storm water, during the warm half-year there was a gradual decrease of outflow. Summer rains, thanks to high air temperatures and plant vegetation, were used mostly for the processes of evapotranspiration. In July and August there were longer periods with total disappearance of outflow, which was particularly observable during a period of atmospheric and hydrological drought in the second year of the study (annual sum of precipitations $422 \mathrm{~mm}$ ). The proposed reservoirs could partially meet the water requirements also during such periods - there is a possibility of their rapid filling during incidental flows of water (e.g. storm flows).

\section{GROUND WATERS}

Groundwater levels in the region of the planned reservoirs were changed periodically - seasonally and annually. They resulted primarily from the varied precipitation supply and outflow. Each hydrological year began and ended with a relatively high level of groundwater level in the bottoms of the valleys, the highest levels being recorded usually in the period from February to April (mainly after thaws). In a year with abundant rainfall a notable increase of groundwater level was observed also at the turn of July and August. In an average and a dry year the greatest lowering of groundwater table occurred from June till August. Groundwater table was notably shallower in the valley bottom than at the foot of the slopes (Fig. 2).
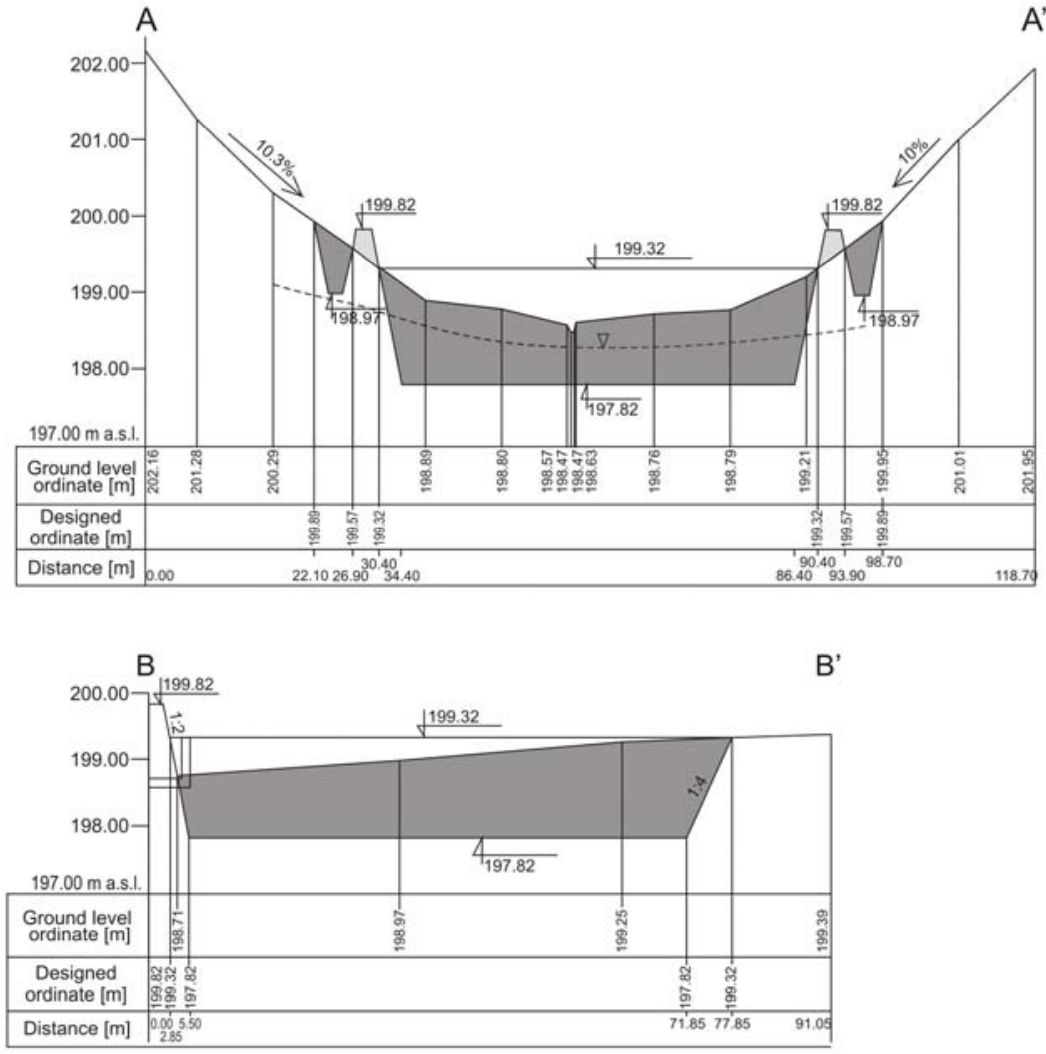

Fig. 2. Transverse cross-section (A-A') and longitudinal (B-B') of the bottom material, light gray - embankment; source: own elaboration

The mean level in the bottoms of the valleys was 23 $\mathrm{cm}$, while at the foot of the slopes about $50 \mathrm{~cm}$ (distance of groundwater table from ground surface). In the valley bottoms the groundwater table often reached the ground surface - in a wet year such high levels persisted in total for nearly five months. The reasons for the persisting waterlogging should also be sought in the grain-size distribution of the surface layer and interbeddings. It creates an impermeable barrier for infiltrating waters.

The lowest level of groundwater table in the valley bottom was noted in a year exceptionally poor in atmospheric precipitation and amounted to $110 \mathrm{~cm}$ (catchment 1). In all of the observation wells the mean groundwater levels in the winter half-years were higher than in the summer half-years. The greatest amplitudes of water levels were noted in the case of sites situated at the foot of the slopes - the maximum 
difference attained $142 \mathrm{~cm}$. In the valley bottoms the range of groundwater table levels was $0-110 \mathrm{~cm}$.

In the period of observations there was a tendency towards groundwater level lowering in the control transects, which was related with reduced precipitation supply. At present the drainage ditch situated in the bottom of the valley does not perform its function. Cessation of maintenance of the melioration structures and the lack of in-depth pre-melioration analysis caused the lack of effects of drainage in the central and lower sections of the main valleys.

\section{CONSTRUCTION OF RESERVOIRS AND EXTENSION OF LANDSCAPE RETENTION}

Due to the existing conditions, it is recommended to construct water reservoirs in the bottoms of the valleys of the slope catchments (Fig. 1-2). The open water surface area will be from 4500 to $7200 \mathrm{~m}^{2}$, with maximum water rise head of $1.5 \mathrm{~m}$ and active capacity of 6050-9880 $\mathrm{m}^{3}$ (Tab. 4).

Table 4. Parameters of water reservoirs

\begin{tabular}{|l|c|c|c|}
\hline \multirow{2}{*}{\multicolumn{1}{|c|}{ Parameter }} & \multicolumn{3}{c|}{ Reservoir } \\
\cline { 2 - 4 } & 1 & 2 & 3 \\
\hline Length / width, $\mathrm{m}$ & $75 / 60$ & $150 / 46$ & $120 / 60$ \\
\hline Total depth, $\mathrm{m}$ & 2 & 2 & 2 \\
\hline Maximum water rise head, $\mathrm{m}$ & 1.5 & 1.5 & 1.5 \\
\hline Water surface area, $\mathrm{m}^{2}$ & 4500 & 6900 & 7200 \\
\hline Maximum active capacity, $\mathrm{m}^{3}$ & 6050 & 9390 & 9880 \\
\hline Volume of earthworks, $\mathrm{m}^{3}$ & 5860 & 8250 & 8335 \\
\hline Protective geomembrane, $\mathrm{m}^{2}$ & 1260 & 1380 & 1800 \\
\hline
\end{tabular}

Source: own study.

The small widths of the valleys and the close vicinity of arable lands are arguments for the construction of dug reservoirs with embankments (Fig. 2). The application of deepening, without free basing of the reservoirs on the natural banks of the valleys, will increase the scope of work and the costs and time of performance, but it will reduce to the minimum the necessity of changes in the use of the neighbouring lands and will remove the banks of the planned reservoirs from arable fields. This reduces a threat of contamination by agricultural pollutants [DZIKIEWICZ 2000; EVANS 2012]. In addition, thanks to the deepening it will be possible to get rid of a notable part of organic matter deposited in the bottoms (source of biogenic elements) [BAJKIEWICZ-GRABOWSKA, ZDANOWSKI 2006; JARVIE et al. 2005] and to gain volume without any effect on the neighbouring agricultural lands (groundwater levels). The planned reservoirs will have rectangular shapes - shoreline formation, including embankment construction, will be made with the use of the earth material acquired (Fig. 2). The bottoms of the reservoirs will be levelled in all directions. The adopted longitudinal profiles will prevent the backwater effect of the damming. In the case of reservoirs 1 and 3 it is recommended to construct earth dams, while reservoir 2 will be based on the body of the existing road embankment (Fig. 1). The damming structures will be reinforced and protected with geosynthetics against soaking. Emptying of the reservoirs will be possible thanks to the use of monks. The choice of the outlet structures should take into account the risk of transporting the products of erosion into the reservoir bowls (colmatation cannot interfere with water outflow from the water bodies). The supply of the reservoirs with water can take place with the use of weirs or suitably profiled channels incised into the banks on the inflow side. In the case of the side walls and dams the bank slope should be $1: 2$, while the banks on the inflow side should be formed with slope of 1:4 (Fig. 2) and suitably strengthened, e.g. with stone outlay (there is a possibility downflows on the full width of the valley). In certain cases girdling ditches were also designed, the function of which will be absorb waters flowing down directly from the valley slopes (vicinity of reservoirs 1 and 2) or the small side valley (western bank of reservoir 3) directly to the water courses below the damming profiles.

The suggested location and structure of the reservoirs will not involve any threat to the adjacent areas, presented in the literature [MANATUNGE et al. 2008; MiodUSZEWSKI 2012; ŻBIKOWSKI, ŻELAZO 1993]. As an instance, no technical infrastructure, including buildings, has been noted in the valley bottoms. Though the reservoirs will play the role of biofilters [HARRELL, RANJITHAN 2003], they should also be protected to extend their service life. For this purpose it is necessary to create buffer zones between water and land, introducing special vegetation stopping excessive contamination from getting to the reservoirs (biogeochemical barriers) [CORRELL 2005; MANDER et al. 2005; RYSZKOWSKI et al. 1999]. At this stage it is not planned to build sedimentation tanks above the reservoirs, therefore gradual silting should be expected, and the necessity of periodic removal of sediments from the bottoms should be taken into account. In the case of a high threat on the part of soil erosion products it will be required to designate sedimentation zones, separated from the reservoirs with stone overflows [MOLINA-NAVARRO et al. 2014].

For effective improvement and qualitative protection of water resources an attempt at expanding the landscape retention should also be undertaken [CHEN et al. 2010; SuN et al. 2006]. In the opinion of authors it is necessary to conduct tree plantings on as large area as possible - first on areas with slopes greater than $15 \%$. However, due to the agricultural character of the area and to its very good soils, the application of measures of this kind cannot be a limitation for the agricultural production area. There is a need to create protection of high nature-value landscape interiors, e.g. turf and bush enclaves in the side valleys and on mid-field scarps. As the basic elements of the biological building it is planned to introduce plantings of turfs in the bottoms of the main valleys and on the lines of periodic downflows (17.5 ha), and plantings 
of trees along the roads and in the area of steep slopes (belt, row $-18.8 \mathrm{~km}$, area plantings $-4.4 \mathrm{ha}$ ). In this regard both the selection of tree species and the organisation of the plantings are very important (taking into account the habitat conditions, selection of sites, structure) [WĘGOREK 1985; 1995; ZAJACCZKOWSKI 2001]. Increasing the participation of orchards on the slopes with a slightly smaller falls is also proposed (8 ha).

An important aspect in the construction of small reservoirs in agricultural areas is their effect on raising the groundwater level [HAYASHI, ROSENBERRY 2002; WINTER 1999]. The creation of small reservoirs outside of river valleys is a possible and favourable solution not only from the viewpoint of increasing the water resources of the catchments, but also because it may contribute to an improvement of quality of the waters [MIODUSZEWSKI 2012; WIATKOWSKI 2011; ZUBALA 2009], protection against erosion [PATRO 2008; POWERs et al. 2014] and enhancing the attractiveness of the landscape [BELL 2004; JANECZKO 2009]. Moreover, reservoirs enhance the biodiversity in the agricultural landscape, creating a favourable habitat for aquatic flora and fauna [DAVIES et al. 2008; WiLliams et al. 2004].

\section{CONCLUSIONS}

Many regions of the world face the problem of water deficit. Also in Europe there are countries whose resources do not exceed $1700 \mathrm{~m}^{3}$ a year per one inhabitant. The reasons for this state may be various, but there is only one rapid and effective method of improving the water balance - expansion of retention. Unfortunately, not everywhere there are possibilities of constructing large reservoirs on the main water courses of a drainage basin. In such a situation improvement of water resources should be sought in the sub-catchments, with the use of smaller but more numerous and much cheaper retention reservoirs. This is possible e.g. in strong-relief agricultural areas, where periodic outflows of surface waters is observed. This applies not only to many regions of Poland, but also to other areas in the world with similar characteristics and land use.

In the case of strong-relief agricultural catchments favourable conditions for the construction of small reservoirs occur in waterlogged bottoms of valleys (especially where maintenance of melioration structures has been neglected). The study demonstrated that such places offer favourable opportunities for the construction of small reservoirs with water surface areas of about $7000 \mathrm{~m}^{2}$ and active volumes of nearly $10000 \mathrm{~m}^{3}$. Under the conditions of the study, a single reservoir could retain during an event from 4.5 to $9.7 \%$ of the annual outflow. On loessic areas, in basins of fourth rank (area of about $150 \mathrm{~km}^{2}$ ) there could be as many as 50 side valleys. Construction of one reservoir (with the parameters presented in the article) in each valley could give temporary surface retention at level of $500000 \mathrm{~m}^{3}$. At the same time, the suggested solution does not cause negative effects in natural aquatic ecosystems, as in the case of large dams. Small dams will be located on periodic streams - apart from the main valley. Farmers should be encouraged to seek "own water sources" (retention facilities on land excluded from agricultural use), using appropriate economic instruments. Households that would have shown a significant decrease in the consumption of tap water could be offered appropriate tax incentives.

Due to the high susceptibility of small reservoirs to anthropopressure and to the high probability of its occurrence in agricultural areas, it is necessary to undertake actions, already at the design stage, that will protect the reservoirs against excessive inflow of biogenic elements and eroded soil material. The lack of such solutions (biogeochemical barriers) will cause their rapid eutrophication and silting. It is also important due to the need of efficient operation of such reservoirs which may be an element of protection of natural water bodies against contamination. Particular attention should be paid to the introduction of midfield shelterbelts, which also would contribute to increasing the retention of landscape. Shelterbelts and water reservoirs will also have a significant effect on the improvement of the simplified agricultural landscape and on increasing biodiversity through the diversification of habitats.

\section{Acknowledgements}

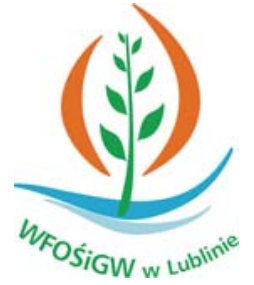

Dofinansowano ze środków

Wojewódzkiego Funduszu Ochrony Środowiska i Gospodarki Wodnej w Lublinie Cofinanced by Voivodeship Fund for Environmental Protection and Water Management in Lublin

\section{REFERENCES}

BAJKIEWICZ-Grabowska E., ZdANOWSKI B. 2006. Phosphorus retention in lake sections of Struga Siedmiu Jezior. Limnological Review. No. 6 p. 5-12.

BeLL S. 2004. Elements of visual design in the landscape. New York. Spon Press London. ISBN 978-0415325189 pp. 224.

BoARDMAN J., Poesen J. 2006. Soil erosion in Europe. Chichester. U.K. Wiley. ISBN 9780470859100 pp. 855.

BOUWER H. 2000. Integrated water management: emerging issues and challenges. Agricultural Water Management. No. 45 p. $217-228$.

Brockerhoff E.G., Jactel H., Parrotta J.A., Quine C.P., SAYER J. 2008. Plantation forests and biodiversity: oxymoron or opportunity? Biodiversity and Conservation. Vol. 17. Iss. 5 p. 925-951.

Chen L., Wang J., Wei W., Fu B., Wu D. 2010. Effects of landscape restoration on soil water storage and water use in the Loess Plateau Region, China. Forest Ecology and Management. Vol. 259. Iss. 7 p. 1291-1298. 
CORRELl D.L. 2005. Principles of planning and establishment of buffer zones. Ecological Engineering. Vol. 24. Iss. 5 p. $433-439$.

DAVIS M. 2007. Integrated water resource management and water sharing. Journal of Water Resources Planning and Management. Vol. 133. Spec. iss. Transboundary Water Sharing p. 427-445.

Davies B., Biggs J., Williams P., Withfield M., Nicolet P., SEAR D., Bray S., MAUND S. 2008. Comparative biodiversity of aquatic habitats in the European agricultural landscape. Agriculture, Ecosystems and Environment. Vol. 125. Iss. 1-4 p. 1-8.

Deitch M.J., Merenlender A.M., Feirer S. 2013. Cumulative effects of small reservoirs on streamflow in Northern Coastal California Catchments. Water Resources Management. Vol. 27. Iss. 15 p. 5101-5118. DOI: 10.1007/s11269-013-0455-4.

DZIKIEWICZ M. 2000. Activities in nonpoint pollution control in rural areas of Poland. Ecological Engineering. Vol. 14. Iss. 4 p. 429-434.

EEA 2012. European waters - current status and future challenges. Synthesis. EEA Report. No 9. ISBN 978-929213-341-2 pp. 52

Eurostat 2011. Energy, transport and environment indicators. Luxembourg. Publications Office of the European Union. ISBN 978-92-79-21384-7 pp. 211.

Evans R. 2012. Reconnaissance surveys to assess sources of diffuse pollution in rural catchments in East Anglia, eastern England - implications for policy. Water and Environment Journal. No 26 p. 200-211.

FAO 2003. Review of world water resources by country. Rome. Water Report. No. 23. ISSN 1020-1203 pp. 111.

GordOn L.J., Finlayson C.M., FalkenMark M. 2010. Managing water in agriculture for food production and other ecosystem services. Agricultural Water Management. Vol. 97. Iss. 4 p. 512-519.

GRAYMAN W.M., LOUCKS D., SAITO L. 2012. Toward a sustainable water future. Visions for 2050. EWRI, ASCE. ISBN 978-0-7844-1207-7 pp. 398.

HARRELl L., RANJithan S. 2003. Detention pond design and land use planning for watershed management. Journal of Water Resources Planning and Management. Vol. 129. Iss. 2 p. 98-106.

HAYASHI M., ROSENBERRY D.O. 2002. Effects of groundwater exchange on the hydrology and ecology of surface waters. Groundwater. Vol. 40. No. 3 p. 309-316.

Hietala-Koivu R., Lankoski J., TARmi S. 2004. Loss of biodiversity and its social cost in an agricultural landscape. Agriculture, Ecosystems and Environment. Vol. 103. Iss. 1 p. $75-83$.

JANECZKO E. 2009. The role and importance of forest watercourses and water reservoirs in designing landscape values of forests. Journal of Water and Land Development. No. 13a p. 177-185.

Jarvie H.P., JÜRgENS M.D., William R.J., NeAl C., DAvieS J.L., BARRETT C., White J. 2005. Role of river bed sediments as sources and sinks of phosphorus across two major eutrophic UK river basins: the Hampshire Avon and Herefordshire Wye. Journal of Hydrology. Vol. 304. Iss. $1-4$ p. $51-74$.

JózeFACIUK A., JózefACIUK C. 1999. Ochrona gruntów przed erozją [Land protection against erosion]. Puławy. IUNG. ISBN 83-88-031-21-X pp. 110.

JuszCZAK R., KęDZIORA A. 2003. Threats to and deterioration of small water reservoirs located within Wyskoć catchment. Polish Journal of Environmental Studies Vol. 12 . No. 5 p. $567-573$.
KAWAMURA S. 2000. Integrated design and operation of water treatment facilities. $2^{\text {nd }}$ ed. New York. Wiley. ISBN 978-0471350934 pp. 720.

KOWALEWSKi Z. 2003. Wpływ retencjonowania wód powierzchniowych na bilans wodny małych zlewni rolniczych [The effect of surface retention on the water balance of small agricultural catchments]. Woda-ŚrodowiskoObszary Wiejskie. Rozprawy naukowe i monografie. $\mathrm{Nr}$ 6. ISBN 83-88763-31-8 pp. 126.

KOWALEWSKI Z. 2008. Actions for small water retention undertaken in Poland. Journal of Water and Land Development. No. 12 p. 155-167.

MAnatunge J., NAKAyAma M., Priyadarshana T. 2008. Environmental and social impacts of reservoirs: issues and mitigation. Oceans and Aquatic Ecosystems. Vol. 1 p. $212-255$.

Mander U., Hayakawa Y., Kuusements V. 2005. Purification processes, ecological functions, planning and design of riparian buffer zones in agricultural watersheds. Ecological Engineering. Vol. 24. Iss. 5 p. 421-432.

MIODUSZEWSKI W. 1994. Ochrona i kształtowanie zasobów wodnych w małych rolniczych zlewniach rzecznych [Protection and water resources shaping in small agricultural river catchments]. Materiały Informacyjne. $\mathrm{Nr}$ 25. Falenty. IMUZ. ISSN 08060-1410 pp. 104.

MiodusZEWSKI W. 2003. Mała retencja. Ochrona zasobów wodnych i środowiska naturalnego. Poradnik [Small retention. Protection of water resources and natural environment. Guidebook]. Falenty. IMUZ. ISBN 83-8876324-5 pp. 49 .

MiodUSZEWSKI W. 2012. Small water reservoirs - their function and construction. Journal of Water and Land Development. No. 17 p. 45-52.

Mirchi A., Watkins D.W. JR, Huckins C.J., Madani K., HJORTH P. 2014. Water resources management in a homogenizing world: Averting the growth and underinvestment trajectory. Water Resources Research. Vol. 50. Iss. 9 p. 7515-7526.

Molina-Navarro E., Martinez-Perez S., SAStre-Merlin A., BiENES-Allas R. 2014. Catchment erosion and sediment delivery in a limno-reservoir basin using a simple methodology. Water Resources Management. Vol. 28. Iss. 8 p. 2129-2143.

PATRO M. 2008. Influence of in-field retention reservoirs on soil outflow from a catchment. Annales of Warsaw University of Life Sciences - SGGW. Land Reclamation. No. 39 p. 103-109.

Patro M., Zubala T. 2012. Possibilities of shaping the water retention in agricultural landscape. Teka Komisji Ochrony i Kształtowania Środowiska Przyrodniczego. T. 9 p. $143-152$.

Powers S.M., RoberTSON D.M., Stanley E.H. 2014. Effects of lakes and reservoirs on annual river nitrogen, phosphorus, and sediment export in agricultural and forested landscapes. Hydrological Processes. Vol. 28. Iss. 24 p. 5919-5937.

Ryszkowski L., BARtoszewicz A., KęDZiora A. 1999. Management of matter fluxes by biogeochemical barriers at the agricultural landscape level. Landscape Ecology. Vol. 14. Iss. 5 p. 479-492.

SKaGGS R.W., Brevé M.A., Gilliam J.W. 1994. Hydrologic and water quality impacts of agricultural drainage. Critical Reviews in Environmental Science and Technology. Vol. 24. Iss. 1 p. 1-32.

Sun G., Zhou G.Y., Zhang A.Q., Wei X.H., McNulty S.G., Vose J.M. 2006. Potential water yield reduction 
due to forestation across China. Journal of Hydrology. No. 328 p. $548-558$.

Van Oost K., Govers G., Desmet P. 2000. Evaluating the effects of changes in landscape structure on soil erosion by water and tillage. Landscape Ecology. Vol. 15. Iss. 6 p. $577-589$.

WĘGOREK T. 1985. Dobór drzew i krzewów do zadrzewień przeciwerozyjnych na wyżynnych terenach Lubelszczyzny [The selection of trees and shrubs for antierosion shelterbelts on upland areas of the Lublin region]. Zeszyty Problemowe Postępów Nauk Rolniczych. Z. 311 p. 125-152.

WĘGOREK T. 1995. Funkcje zadrzewień terenów erodowanych [Functions of shelterbelts on eroded areas]. Wiadomości Melioracyjne i Łąkarskie. Nr 2 p. 83-84.

White P., LABADZ J.C., BUTCHER D.P. 1996. The management of sediment in reservoired catchments. Water and Environment Journal. Vol. 10. Iss. 3 p. 183-189.

WiATKOWSKI M. 2011. Influence of Słup dam reservoir on flow and quality of water in the Nysa Szalona River.
Polish Journal of Environmental Studies. Vol. 20. Iss. 2 p. 469-478.

Williams P., Whitfield M., Biggs B., Bray S., Fox G., NiCOLET P., SEAR D. 2004. Comparative biodiversity of rivers, streams, ditches and ponds in an agricultural landscape in Southern England. Biological Conservation. Vol. 115. Iss. 2 p. 329-341.

WINTER T.C. 1999. Relation of stream, lakes and wetlands to groundwater flow systems. Hydrogeology Journal. Vol. 7. Iss. 1 p. $28-45$.

ZAJĄCZKOWSKI K. 2001. Dobór drzew i krzewów do zadrzewień na obszarach wiejskich [The selection of trees and shrubs for afforestation in rural areas]. Warszawa. IBL. ISBN 83-87647-25-X pp. 78.

ZUBALA T. 2009. Influence of dam reservoir on the water quality in a small upland river. Ecohydrology and Hydrobiology. Vol. 9. Iss. 2-4 p. 165-173.

ŻBIKOWSKI A., ŻELAZO J. 1993. Ochrona środowiska w budownictwie wodnym [Environmental protection in water constructions]. Warszawa. Falstaff. ISBN 83901312-0-X pp. 156.

\section{Tomasz ZUBALA, Magdalena PATRO}

\section{Potencjalne możliwości retencjonowania wody w rolniczych zlewniach lessowych}

\section{STRESZCZENIE}

Rosnący deficyt i zwiększone zapotrzebowanie na wodę, jak również problemy ekonomiczne i niewłaściwe planowanie przestrzenne w wielu regionach wskazują na konieczność wypracowania bardziej efektywnych zasad programowania i realizacji zadań w zakresie gospodarki wodnej w małych zlewniach. W pracy przedstawiono przykładową analizę możliwości zwiększenia retencji wodnej w rolniczych zlewniach lessowych z ciekami okresowymi. W ramach badań wyznaczono parametry fizyczne wybranych zlewni cząstkowych (geometria, pokrywa glebowa, zagospodarowanie itp.) oraz określono źródła zagrożeń zasobów wodnych, wynikających z warunków urządzeniowych i geomorfologicznych. Wykonano założenia przedprojektowe piętrzeń z uwzględnieniem zabezpieczeń przeciwerozyjnych oraz zaproponowano zabiegi zwiększające krajobrazową retencję wodną. Tworzenie obiektów retencji powierzchniowej powinno być ważnym źródłem wody w uproszczonych agrosystemach, zwłaszcza w regionach, w których produktywność w dużym stopniu zależy od naturalnych warunków pogodowych. Dzięki właściwemu zagospodarowaniu lessowego dorzecza IV rzędu rzeki Ciemięgi (powierzchnia około $150 \mathrm{~km}^{2}$, obecność ok. 50 dolin bocznych) można by uzyskać chwilową retencję zbiornikową sięgającą $500000 \mathrm{~m}^{3}$. Należy zachęcać rolników do poszukiwania „własnych źródeł wody” (m.in. gromadzenie wody w obrębie nieużytków), stosując odpowiednie instrumenty ekonomiczne (ulgi podatkowe za udokumentowaną objętość retencjonowanej wody, np. w zbiornikach małej retencji).

Słowa kluczowe: retencja, zasoby wodne, zbiorniki, zlewnia rolnicza 